Original Contribution

\title{
CHARACTERISTICS AND PROXIMATE COMPOSITION OF JAPANESE QUAIL (COTURNIX JAPONICA) CARCASS IN A SEMI ARID AREA OF NIGERIA
}

\author{
A. O. Raji*, A. Y. Girgiri, N. K. Alade, S. A. Jauro \\ Department of Animal Science, University of Maiduguri, Maiduguri, Nigeria.
}

\begin{abstract}
Characteristics and proximate compositions of Japanese quail carcass in a semi arid area of Nigeria were determined at the Poultry Unit of the Department of Animal Science, University of Maiduguri using 300 random bred Japanese quail. Sex, color type, weight group and age had significant effects on carcass characteristics. Sexual dimorphism was in favor of the females for most carcass characteristics; however, dressed percent $(72.41 \%)$ was significantly higher in males than females $(68.02 \%)$. Wild type Japanese quails had significantly higher slaughter weight (132.66 g) than light brown (121.33 g). The values for most carcass traits increased with increase in age and weight of birds. Abdominal fat deposit in the Japanese quail became noticeable only at 24 weeks $(1.39 \mathrm{~g})$ of age and increased to $10.70 \mathrm{~g}$ at 52 weeks. The mean values of moisture, dry matter, protein, ether extract and ash in whole Japanese quail carcass were $78.22,21.78,15.55,12.23$ and $2.91 \%$, respectively. The corresponding values for breast meat were $78.88,21.12,17.90,2.01$ and $2.28 \%$ while those of thigh were 82.28, 17.72, 13.63, 2.91 and 2.86\%. Age had effect on composition of whole carcass, breast and thigh meats, moisture content of whole quail carcass decreased with a reversing trend for dry matter, crude protein and ether extract. At 6 weeks of age, moisture in whole quail was $14.85 \%$ higher than at 24 weeks. In contrast, at 24 weeks dry matter, crude protein and ether extract were 11.06, 7.89 and $17.32 \%$ respectively, higher than at 6 weeks. Similar trends were observed for breast and thigh meats, though the former had better quality.
\end{abstract}

Key words: carcass, traits, proximate, Japanese quail

\section{INTRODUCTION}

The poultry industry has high potential for increasing protein output for human consumption since the consumption of poultry meat and its product is growing all over the world (1). The Japanese quail is an additional source of animal protein for human consumption. They are kept for both commercial and scientific purposes. The meat and egg are delicious, noted for high dietary and even medicinal values (2). The meat is lean and both the egg and meat are low in cholesterol (3). Quails could be a good and economical source of animal protein because of their fast growth potential, early maturity, high rate of egg production, short generation interval and small body size that allows large number of birds to be kept in a small space. Studies have shown that in Japanese quails, the percentage edible meat is higher than in most poultry species; indicating its high efficiency for meat production. (4)

\footnotetext{
*Correspondence to: Raji, A.O., Department of Animal Science, University of Maiduguri, Maiduguri, Nigeria,razrajpearl@yahoo.com
}

reported that quails slaughtered at 5 - 6 weeks had dressing percentage of $60-80 \%$ with an average of $75 \%$ which is much higher than in broiler chickens of the same age.

Quality is an important attribute affecting consumer reaction to poultry product. Genotype, age, diet and gender are important factors determining the chemical composition of poultry meat particularly protein and fat content (5). The quality of poultry meat is also affected by numerous factors associated with either the animal or its environment, such as age, sex, breed, species, rearing and feeding system, handling and slaughtering conditions (6). Specifically, it has been demonstrated that factors such as sex, age, diet formulation and strain affect the carcass characteristics of Japanese quails (7). Moisture

content of quail carcass tends to decrease, while fat increased with advancing age (8). (9) earlier found that age of quail had a significant effect on carcass water, fat and protein composition. It was also reported that as from 2 to 8 weeks of age carcass moisture content declined and fat content increased while protein content 
increased up to 4 weeks and then decreased at 8 weeks of age.

Presently, there is scanty information on carcass characteristics and composition of Japanese quails in Nigeria. The aim of this study was to determine the characteristics and proximate composition of Japanese quail carcass.

\section{MATERIALS AND METHODS}

The study was carried out at the Poultry Unit of the University of Maiduguri Livestock Teaching and Research Farm, Maiduguri, Borno State, Nigeria. Maiduguri, the Borno State capital is situated on latitude $11^{0} 5^{\prime} \mathrm{N}$, longitude $13^{0} 09^{\prime} \mathrm{E}$ and at an altitude of $354 \mathrm{~m}$ above sea level. The area falls within the Sahelian region of West Africa, which is noted for great climatic and seasonal variations. It has very short period $(3-4$ months) of rainfall of $645.9 \mathrm{~mm} / \mathrm{annum}$ with a long dry season of about $8-9$ months. Relative humidity is usually $45 \%$ in August and drops to about 5\% in December and January. Day length varies from 11 to 12 hours.

Three hundred Japanese quails hatched from eggs laid by a random mating flock maintained at the Poultry Unit of the University of Maiduguri Livestock Teaching and Research Farm was used for the study. They were brooded for four weeks before being divided into cages $(30 \times 30 \times 45 \mathrm{~cm})$ fitted with feeders and drinkers. A commercial broiler starter diet containing $23 \%$ crude protein and $3000 \mathrm{kcal} / \mathrm{kg}$ energy was fed from 0-6 weeks and a breeder's diet containing $18 \%$ crude protein and $2800 \mathrm{kcal} / \mathrm{kg}$ thereafter. All the birds had access to feed and water ad libitum.

Birds for carcass evaluation were fasted for 12 hours, weighed, slaughtered, bled, plucked and eviscerated and cut into different portions. Carcass traits were determined at 6, 8, 12, 16, 20, 32 and 52 weeks of age. The traits included; slaughter and carcass weights, breast and thigh percents as well as carcass yield or dressing percent which was determined as:

$$
\begin{gathered}
\text { Dressed percent }= \\
\frac{\text { dressed carcass weight }}{\text { live body weight }} \times 100
\end{gathered}
$$

\section{Proximate Analysis of Carcass}

The proximate analysis was carried out at the Animal Science laboratory of the University of Maiduguri using methods described by (10). The proximate principles determined were crude protein, dry matter, ether extract and ash content.

\section{Statistical analysis}

The data generated was analyzed using the General Linear Model of SPSS 13.0 (11) with age, sex, weight and color type as fixed factors. Significant means were separated by Duncan's Multiple Range Test. The model for the analysis is as follows:

$\mathrm{Y}_{\mathrm{ijklm}}=\mathrm{A}_{\mathrm{i}}+\mathrm{B}_{\mathrm{j}}+\mathrm{C}_{\mathrm{k}}+\mathrm{D}_{\mathrm{l}}+\mathrm{e}_{\mathrm{ijk} \mathrm{m}}$

Where $Y_{\mathrm{ijklm}}=$ individual observation based on the ijklm classification

$\mathrm{A}_{\mathrm{i}}=$ effect of age

$B_{j}=$ effect of sex

$\mathrm{C}_{\mathrm{k}}=$ effect of color type

$\mathrm{D}_{1}=$ effect of weight group

$\mathrm{e}_{\mathrm{ijklm}}=$ random error

\section{RESULTS AND DISCUSSION Carcass Characteristics}

The effects of sex, color type, weight and age on carcass characteristics of the Japanese quail are presented in Table 1. The mean live and carcass weights were 130.56 and $91.65 \mathrm{~g}$, and dressed, breast, thigh and back percentages were 70.24, $29.98,21.70$ and $36.41 \%$, respectively. Similarly, the effects of sex, color type, weight and age on organ and fat percent of the Japanese quail are presented in Table 2. The mean values of heart, liver, proventriculus, testes, gizzard and fat percent are $0.71,2.49,0.48,0.74,3.46$ and $1.07 \%$, respectively.

\section{Effect of sex}

Sex had significant effect on live weight, dressed, heart, liver, proventriculus and fat percent $(\mathrm{P}<0.001)$ and back $(\mathrm{P}<0.05)$. The effect was not significant for carcass weight, breast, thigh and gizzard percent. Where significant, sexual dimorphism was in favor of females except dressed percent where males dressed $(72.41 \%)$ better than females $(68.02 \%)$. This can be attributed to better live weight of the females (134.73 g) compared to males (126.49 g). Similar, results were recorded for internal organs (liver, proventriculus and gizzard) and fat weights. In contrast, males had higher back (39.06 vs $33.71 \%$ ) and heart (0.75 vs $0.67 \%)$ percents.

The generally significant effect of sex on carcass characteristics of the Japanese quail had been reported $(12,13)$. (12) also reported nonsignificant effect of sex on carcass weight as observed. The higher live weight of females observed in this study has also been reported by (12) and (14). (12) reported live weight values of 104 and $134 \mathrm{~g}$ for males and females, respectively which are close to those reported in this study. 
RAJI A. O., et al.

Table 1. Effects of sex, color type, weight group and age on carcass characteristics of the Japanese quail

\begin{tabular}{lcccccc}
\hline & $\begin{array}{l}\text { Live } \\
\text { weight }(\mathrm{g})\end{array}$ & $\begin{array}{l}\text { Carcass } \\
\text { weight }(\mathrm{g})\end{array}$ & $\begin{array}{l}\text { Dressed } \\
\text { percent }\end{array}$ & $\begin{array}{l}\text { Breast } \\
\text { percent }\end{array}$ & $\begin{array}{l}\text { Thigh } \\
\text { percent }\end{array}$ & $\begin{array}{l}\text { Back } \\
\text { percent }\end{array}$ \\
\hline Overall mean & 130.56 & 91.65 & 70.24 & 29.98 & 21.7 & 36.41 \\
Color & $*$ & $\mathrm{~ns}$ & $\mathrm{~ns}$ & $\mathrm{~ns}$ & $\mathrm{~ns}$ & $\mathrm{~ns}$ \\
Wild type & $132.66^{\mathrm{a}}$ & 92.46 & 70.07 & 31.02 & 22.21 & 35.69 \\
Light brown & $121.33^{\mathrm{b}}$ & 88.12 & 70.96 & 25.45 & 19.47 & 39.6 \\
Sex & $* * *$ & $\mathrm{~ns}$ & $* * *$ & $\mathrm{~ns}$ & $\mathrm{~ns}$ & $*$ \\
Male & $126.49^{\mathrm{b}}$ & 92.75 & $72.41^{\mathrm{a}}$ & 30.05 & 22.01 & $39.06^{\mathrm{a}}$ \\
Female & $134.73^{\mathrm{a}}$ & 90.53 & $68.02^{\mathrm{b}}$ & 29.91 & 21.39 & $33.71^{\mathrm{b}}$ \\
& & & & & & \\
body weight groups & $* * *$ & $* * *$ & $\mathrm{~ns}$ & $\mathrm{~ns}$ & $\mathrm{~ns}$ & $\mathrm{~ns}$ \\
Light & $114.77^{\mathrm{c}}$ & $78.56^{\mathrm{c}}$ & 68.9 & 32.97 & 24.23 & 37.95 \\
Medium & $126.83^{\mathrm{b}}$ & $89.99^{\mathrm{b}}$ & 71.49 & 29.24 & 20.81 & 33.37 \\
Heavy & $146.39^{\mathrm{a}}$ & $103.48^{\mathrm{a}}$ & 72.17 & 28.3 & 20.53 & 37.97 \\
Age (weeks) & $* * *$ & $* * *$ & $\mathrm{~ns}$ & $\mathrm{~ns}$ & $\mathrm{~ns}$ & $\mathrm{~ns}$ \\
6 & $97.19^{\mathrm{e}}$ & $67.60^{\mathrm{d}}$ & 69.61 & 23.31 & 18.95 & 36.26 \\
8 & $119.93^{\mathrm{d}}$ & $86.57^{\mathrm{c}}$ & 72.35 & 31.04 & 20.39 & 34.7 \\
10 & $132.00^{\mathrm{bc}}$ & $93.42^{\mathrm{c}}$ & 71.03 & 33.39 & 22.42 & 30.61 \\
16 & $134.44^{\mathrm{bc}}$ & $92.35^{\mathrm{c}}$ & 68.89 & 32.49 & 22.51 & 34.36 \\
20 & $129.72^{\mathrm{cd}}$ & $89.82^{\mathrm{c}}$ & 69.3 & 29.46 & 22.02 & 32.55 \\
24 & $142.11^{\mathrm{b}}$ & $96.98^{\mathrm{bc}}$ & 68.55 & 30.35 & 22.44 & 34.08 \\
30 & $154.33^{\mathrm{a}}$ & $104.14^{\mathrm{b}}$ & 68.09 & 31.16 & 22.84 & 35.38 \\
52 & $162.67^{\mathrm{a}}$ & $119.54^{\mathrm{a}}$ & 69.82 & 33.45 & 24.51 & 30.12 \\
SEM & 2.07 & 1.7 & 0.61 & 0.24 & 0.12 & 0.39 \\
\hline
\end{tabular}

$\mathrm{a}^{\mathrm{bc}}$ Means in a column within a subset with different superscript are significantly $(\mathrm{P}<0.05)$ different $* * *=\mathrm{P}<0.001, * *=\mathrm{P}<0.01, *=\mathrm{P}<0.05, \mathrm{~ns}=$ not significant

However, (13) and (14) observed higher male than female respective values. The significantly higher dressing percentage of males than females observed also agrees with the findings of (12) and (14). (12) reported dressing percentages of males and females (72.39 and 62.06\%) that are similar to values of this study. (15) postulated that the higher dressing percentage of males as compared to females in spite of lower live body weight may be due to larger bones and lighter internal organs of males than females. (16) also reported that breast and leg weights were affected by sex. While better liver and gizzard weights observed in females corresponds with the observations of (13) that of abdominal fat is in line with the observation of (17). However, (14) reported higher abdominal fat for males than females.

\section{Effect of color type}

Color type did not have significant effect on most carcass characteristics except live weight. Wild type quails had higher live weight (132.66 vs $121.33 \mathrm{~g})$ compared to the light brown. With respect to organs, color type significantly affected heart, testes and fat percent. The light brown quails had higher fat compared to the wild type which had larger heart and testes.

\section{Effect of weight group}

Weight group had significant $(\mathrm{P}<0.001)$ effect on live and carcass weights, and back and fat percents. Organ weights were also significantly $(\mathrm{P}<0.001)$ affected. The values for all carcass traits increased with increasing body weight. The light, medium and heavy weight groups respectively had live weights of $114.77,126.83$ and $146.39 \mathrm{~g}$, carcass weights $78.56,89.99$ and $103.48 \mathrm{~g}$ and dressed percent 68.90, 71.49 and $72.17 \%$, respectively. A similar trend was observed for organ and fat percent. This is probably because heavier animals are more likely to have heavier body parts and organs. (18) found that carcass weight and all carcass components of Japanese quail were positively influenced by live body weight. (19) also made similar observations.

\section{Effect of age}

Age of birds significantly $(\mathrm{P}<0.001)$ affected live and carcass weights as well as organ percent. Where significant effect was observed, the values for most carcass traits tended to increase with increase in age. Abdominal fat deposition became noticeable at 24 weeks $(0.96 \%)$ of age and increased to $5.89 \%$ of the body weight at 52 weeks of age. Live weight also increased from $97.19 \mathrm{~g}$ at 6 weeks to $162.67 \mathrm{~g}$ at 52 weeks. Similarly, carcass weight which ranged from 67.60 - $119.54 \mathrm{~g}$ also increased from 6 to 52 weeks. (8) and (20) reported similar significant age effect on carcass characteristics. 
RAJI A. O., et al.

The non significant effect of age on dressing percentage observed in this study had also been previously reported by (21) and (22). (22) estimated dressed percent at 5, 6 and 7 weeks of age as $65.5,65.3$ and $65.2 \%$. (21) also reported dressed percentages of $85.18,85.58,85.0484 .04$ and $86.36 \%$ at $4,5,6,7$ and 8 weeks of age.
However, (23) reported significant age effect on dressed percentage with values of $57.18 \%$ at 22 weeks and, 60.82 and $63.81 \%$ for those aged 16 and 12 weeks. As observed in this study, fat deposition increased with age which is related to maturity and happens in majority of species (24).

Table 2. Effects of sex, color type, weight group and age on organ and fat percent of the Japanese quail

\begin{tabular}{|c|c|c|c|c|c|c|}
\hline & $\begin{array}{l}\text { Heart } \\
(\%)\end{array}$ & $\begin{array}{l}\text { Liver } \\
(\%)\end{array}$ & $\begin{array}{c}\text { Proventriculus } \\
(\%)\end{array}$ & $\begin{array}{l}\text { Testes } \\
(\%)\end{array}$ & $\begin{array}{c}\text { Gizzard } \\
(\%)\end{array}$ & Fat $(\%)$ \\
\hline Overall mean & 0.71 & 2.49 & 0.48 & 0.74 & 3.46 & 1.07 \\
\hline Color & $* *$ & ns & ns & $* *$ & ns & $* * *$ \\
\hline Wild type & $0.72^{\mathrm{a}}$ & 2.45 & 0.48 & $0.80^{\mathrm{a}}$ & 3.43 & $0.77^{\mathrm{b}}$ \\
\hline Light brown & $0.65^{\mathrm{b}}$ & 2.68 & 0.47 & $0.46^{\mathrm{b}}$ & 3.57 & $2.38^{\mathrm{a}}$ \\
\hline Sex & $* * *$ & $* * *$ & $* * *$ & - & ns & $* * *$ \\
\hline Male & $0.75^{\mathrm{a}}$ & $2.08^{\mathrm{b}}$ & $0.44^{\mathrm{b}}$ & - & 3.43 & $0.41^{\mathrm{b}}$ \\
\hline Female & $0.67^{\mathrm{b}}$ & $2.91^{\mathrm{a}}$ & $0.51^{\mathrm{a}}$ & - & 3.49 & $1.72^{\mathrm{a}}$ \\
\hline Body weight groups & $*$ & $* *$ & ns & ns & $* *$ & $* * *$ \\
\hline Light & $0.72^{\mathrm{ab}}$ & $2.77^{\mathrm{a}}$ & 0.49 & 0.83 & $3.64^{\mathrm{a}}$ & $0.20^{\mathrm{b}}$ \\
\hline Medium & $0.67^{\mathrm{b}}$ & $2.50^{\mathrm{ab}}$ & 0.49 & 0.61 & $3.56^{\mathrm{a}}$ & $0.56^{\mathrm{b}}$ \\
\hline Heavy & $0.74^{\mathrm{a}}$ & $2.27^{b}$ & 0.45 & 0.78 & $3.23^{b}$ & $2.22^{\mathrm{a}}$ \\
\hline Age (weeks) & $* * *$ & $* * *$ & $* * *$ & $* * *$ & $* * *$ & $* * *$ \\
\hline 6 & $0.60^{\mathrm{c}}$ & $3.59^{\mathrm{a}}$ & $0.59^{\mathrm{a}}$ & $0.08^{c}$ & $4.12^{\mathrm{a}}$ & $0.00^{\mathrm{c}}$ \\
\hline 8 & $0.81^{\mathrm{a}}$ & $2.17^{\mathrm{c}}$ & $0.44^{\mathrm{b}}$ & $0.52^{\mathrm{bc}}$ & $3.76^{\mathrm{ab}}$ & $0.00^{\mathrm{c}}$ \\
\hline 10 & $0.59^{c}$ & $2.72^{b}$ & $0.47^{\mathrm{b}}$ & $0.78^{\mathrm{ab}}$ & $3.52^{\mathrm{b}}$ & $0.00^{\mathrm{c}}$ \\
\hline 16 & $0.81^{\mathrm{a}}$ & $2.25^{\mathrm{c}}$ & $0.46^{\mathrm{b}}$ & $0.83^{\mathrm{ab}}$ & $3.44^{\mathrm{bc}}$ & $0.00^{\mathrm{c}}$ \\
\hline 20 & $0.71^{b}$ & $2.20^{\mathrm{c}}$ & $0.46^{b}$ & $1.19^{\mathrm{a}}$ & $3.78^{\mathrm{ab}}$ & $0.00^{c}$ \\
\hline 24 & $0.75^{\mathrm{ab}}$ & $2.19^{c}$ & $0.45^{b}$ & $1.19^{\mathrm{a}}$ & $3.13^{c}$ & $0.96^{\mathrm{b}}$ \\
\hline 30 & $0.79^{\mathrm{ab}}$ & $2.18^{\mathrm{c}}$ & $0.44^{\mathrm{b}}$ & $1.19^{\mathrm{a}}$ & $2.59^{\mathrm{d}}$ & $1.77^{\mathrm{b}}$ \\
\hline 52 & $0.71^{\mathrm{b}}$ & $1.86^{\mathrm{c}}$ & $0.44^{b}$ & $1.46^{\mathrm{a}}$ & $2.76^{\mathrm{d}}$ & $5.89^{a}$ \\
\hline SEM & 0.01 & 0.07 & 0.01 & 0.08 & 0.06 & 0.22 \\
\hline
\end{tabular}

\section{Carcass Composition Whole Carcass}

The effects of sex, weight group and age on whole carcass of Japanese quail are presented in Table 3. The mean values of moisture, dry matter, protein, ether extract and ash in whole Japanese quail carcass are $78.22,21.78,15.55,3.53$ and $1.41 \%$ respectively. Among the factors, only age had significant effect on carcass composition except ash. Moisture content of the quail carcass decreased with age while dry matter, crude protein and ether extract increased. Moisture content at 6 weeks of age was $11.06 \%$ higher than $74.50 \%$ at 24 weeks. In contrast, dry matter, crude protein and ether extract were higher at 24 weeks by
$11.06,7.89$ and $2.32 \%$, respectively than the corresponding values at 6 weeks $(14.44,10.32$ and $2.24 \%$ ). The significant effect of age on carcass composition had been reported (25). The decrease in moisture and increase in dry matter, protein and ether extract with age was also reported $(26 ; 27)$. (8) and (25) reported decreased water content and increased fat with advancing age of quails. While (8) observed that protein did not vary (25) reported a decrease with age. These differences could be due to the different diets fed and ages involved in the studies. The non significant effect of sex on carcass composition observed in this study was also reported by (8). Though, (5) reported non significant effect of sex on dry 
RAJI A. O., et al.

matter and ash, their report revealed that ether extract was significantly higher in females than males. (28) also made similar observation with respect to ether extract. Weight group did not affect carcass composition. This agrees with the report of (29) that dry matter, crude fibre, crude protein, moisture content and ether extract are not affected by weight.

Table 3. Effects of sex, weight group and age on proximate composition on whole carcass of Japanese quail.

\begin{tabular}{|c|c|c|c|c|c|}
\hline & \multicolumn{5}{|c|}{ Proximate composition (\%) } \\
\hline & Moisture & Dry matter & $\begin{array}{l}\text { Crude } \\
\text { Protein }\end{array}$ & $\begin{array}{l}\text { Ether } \\
\text { Extract }\end{array}$ & Ash \\
\hline Overall & $78.22 \pm 1.16$ & $21.78 \pm 1.16$ & $15.55 \pm 0.83$ & $3.53 \pm 0.76$ & $1.41 \pm 0.39$ \\
\hline Age (weeks) & & $* *$ & $* * *$ & $* * *$ & ns \\
\hline 6 & $85.56 \pm 2.30^{\mathrm{a}}$ & $14.44 \pm 2.30^{\mathrm{b}}$ & $10.32 \pm 1.64^{\mathrm{b}}$ & $2.24 \pm 1.52^{\mathrm{b}}$ & $1.37 \pm 0.77$ \\
\hline 12 & $80.43 \pm 2.30^{\mathrm{ab}}$ & $19.57 \pm 2.30^{b}$ & $13.97 \pm 1.64^{\mathrm{b}}$ & $2.81 \pm 1.52^{\mathrm{b}}$ & $1.46 \pm 0.77$ \\
\hline 16 & $72.40 \pm 2.49^{b}$ & $27.60 \pm 2.49^{\mathrm{a}}$ & $19.71 \pm 1.78^{\mathrm{a}}$ & $4.31 \pm 1.65^{\mathrm{a}}$ & $1.48 \pm 0.83$ \\
\hline 24 & $74.50 \pm 2.25^{\mathrm{b}}$ & $25.50 \pm 2.25^{\mathrm{a}}$ & $18.21 \pm 1.60^{\mathrm{a}}$ & $4.56 \pm 1.49^{\mathrm{a}}$ & $1.34 \pm 0.75$ \\
\hline Sex & ns & ns & ns & ns & ns \\
\hline Male & $77.79 \pm 1.68$ & $22.21 \pm 1.68$ & $15.86 \pm 1.20$ & $4.00 \pm 1.11$ & $1.46 \pm 0.56$ \\
\hline Female & $78.66 \pm 1.61$ & $21.34 \pm 1.61$ & $15.24 \pm 1.15$ & $2.46 \pm 1.06$ & $1.36 \pm 0.54$ \\
\hline Weight & ns & ns & ns & ns & ns \\
\hline Light & $78.58 \pm 2.16$ & $21.42 \pm 2.16$ & $15.30 \pm 1.55$ & $2.36 \pm 1.43$ & $1.75 \pm 0.72$ \\
\hline Medium & $77.97 \pm 2.01$ & $22.03 \pm 2.01$ & $15.74 \pm 1.44$ & $1.16 \pm 1.33$ & $1.63 \pm 0.67$ \\
\hline Heavy & $78.12 \pm 1.95$ & $21.88 \pm 1.95$ & $15.63 \pm 1.39$ & $3.17 \pm 1.29$ & $1.36 \pm 0.65$ \\
\hline
\end{tabular}

\section{Breast meat}

The effects of sex, color type, weight and age on breast meat of Japanese quail are presented in Table 4. The mean values of moisture, dry matter, protein, ether extract and ash in breast meat are $78.88,21.12,17.90,1.55$ and $1.28 \%$ respectively. Age and sex had significant effects on moisture, dry matter and protein content of breast meat of Japanese quail. The effect of weight was not significant. It was observed that moisture content of the breast decreased with age while dry matter and crude protein increased. Thus, at 6 weeks of age, quail carcass had significantly higher $(84.38 \%)$ moisture than at $12(78.95 \%), 16$ $(79.08 \%)$ and $24(72.05 \%)$ weeks of age. In contrast, dry matter and crude protein respectively were higher at 24 weeks (27.95 and $23.69 \%$ ) than 6 (15.62 and 13.24\%). Moisture content of male breast was higher than females (81.31 vs $77.06 \%$ ). In contrast, dry matter and CP were higher in females than males (18.69 and 15.84 vs 22.94 and $19.44 \%$ ). The significant effect of age and sex on breast meat reported in this study is at variance with that of (28) who did not observe effect of any of these factors.

\section{Thigh meat}

The effects of sex, weight group and age on thigh meat of Japanese quail are presented on Table 5.
The mean values of moisture, dry matter, protein, ether extract and ash in breast meat are 82.28, 17.72, 13.63, 1.91 and $1.86 \%$ respectively. Age had significant effect on moisture, dry matter and crude protein of thigh while sex and weight only affected ether extract significantly. As previously observed with whole carcass and breast, moisture decreased with age while crude protein and dry matter increased. Ether extract was higher in females ( 2.18 vs $1.63 \%$ ) compared to males while the heavy weight group $(2.80 \%)$ had higher value than medium $(1.40 \%)$ and light $(1.53 \%)$. Non significant effect of sex on leg meat composition agrees with most of the results of (28). A comparison of breast and thigh meat showed the superiority of the former over the latter as earlier reported by (28).

\section{CONCLUSION}

Carcass characteristics of Japanese quail was affected by age and sex. Though, females had higher slaughter weight, males dressed better. Generally, quail carcass composition is not affected by sex or weight of the bird, but female breast cut was higher in protein and dry matter than those of the male. Thus, both male and female quails can be raised for meat. 
RAJI A. O., et al.

Table 4. Effects of sex, weight group and age on proximate composition of breast meat of Japanese quail.

\begin{tabular}{|c|c|c|c|c|c|}
\hline & \multicolumn{5}{|c|}{ Proximate composition (\%) } \\
\hline & Moisture & Dry matter & Crude Protein & $\begin{array}{l}\text { Ether } \\
\text { Extract }\end{array}$ & Ash \\
\hline Overall & $78.88 \pm 1.62$ & $21.12 \pm 1.62$ & $17.90 \pm 1.37$ & $1.55 \pm 0.21$ & $1.28 \pm 0.44$ \\
\hline Age (weeks) & $* *$ & $* *$ & $* *$ & ns & ns \\
\hline 6 & $84.38 \pm 3.07^{\mathrm{a}}$ & $15.62 \pm 3.07^{\mathrm{c}}$ & $13.24 \pm 2.60^{\mathrm{c}}$ & $1.33 \pm 0.42$ & $1.83 \pm 1.19$ \\
\hline 12 & $78.95 \pm 1.18^{\mathrm{b}}$ & $21.06 \pm 1.18^{\mathrm{b}}$ & $17.84 \pm 1.00^{\mathrm{b}}$ & $1.17 \pm 0.65$ & $1.83 \pm 0.31$ \\
\hline 16 & $79.08 \pm 2.76^{\mathrm{b}}$ & $20.92 \pm 2.76^{\mathrm{b}}$ & $17.73 \pm 3.13^{b}$ & $1.67 \pm 0.29$ & $1.08 \pm 1.05$ \\
\hline 24 & $72.05 \pm 3.69^{c}$ & $27.95 \pm 3.69^{\mathrm{a}}$ & $23.69 \pm 2.34^{\mathrm{a}}$ & $1.87 \pm 0.28$ & $1.35 \pm 0.52$ \\
\hline Sex & $*$ & $*$ & $*$ & ns & ns \\
\hline Male & $81.31 \pm 2.69^{\mathrm{a}}$ & $18.69 \pm 2.69^{b}$ & $15.84 \pm 2.28^{\mathrm{b}}$ & $1.03 \pm 0.31$ & $1.39 \pm 0.69$ \\
\hline Female & $77.06 \pm 1.92^{\mathrm{b}}$ & $22.94 \pm 1.92^{\mathrm{a}}$ & $19.44 \pm 1.63^{\mathrm{a}}$ & $1.99 \pm 0.30$ & $1.17 \pm 0.56$ \\
\hline Weight & ns & ns & ns & ns & ns \\
\hline Light & $81.65 \pm 2.62$ & $18.35 \pm 2.62$ & $15.55 \pm 2.22$ & $1.08 \pm 0.34$ & $1.66 \pm 0.61$ \\
\hline Medium & $78.28 \pm 2.88$ & $21.72 \pm 2.88$ & $18.41 \pm 2.44$ & $1.58 \pm 0.31$ & $1.71 \pm 0.68$ \\
\hline Heavy & $77.34 \pm 2.93$ & $22.66 \pm 2.93$ & $19.21 \pm 2.48$ & $1.38 \pm 0.42$ & $1.53 \pm 0.93$ \\
\hline
\end{tabular}

Table 5. Effects of sex, weight group and age on proximate composition of thigh meat of Japanese quail.

\begin{tabular}{|c|c|c|c|c|c|}
\hline & \multicolumn{5}{|c|}{ Proximate composition $(\%)$} \\
\hline & Moisture & Dry matter & Crude Protein & $\begin{array}{l}\text { Ether } \\
\text { Extract }\end{array}$ & Ash \\
\hline Overall & 82.281 .68 & $17.72 \pm 1.68$ & $13.63 \pm 1.29$ & $1.91 \pm 0.69$ & $1.86 \pm 0.50$ \\
\hline Age (weeks) & $* *$ & $* *$ & $* *$ & ns & ns \\
\hline 6 & $89.23 \pm 1.29^{\mathrm{a}}$ & $10.78 \pm 1.29^{\mathrm{b}}$ & $8.29 \pm 0.99^{\mathrm{b}}$ & $0.33 \pm 0.61$ & $1.67 \pm 0.61$ \\
\hline 12 & $82.32 \pm 2.46^{\mathrm{ab}}$ & $17.68 \pm 2.46^{\mathrm{ab}}$ & $13.60 \pm 1.89^{\mathrm{ab}}$ & $1.00 \pm 2.65$ & $1.83 \pm 1.14$ \\
\hline 16 & $74.36 \pm 1.46^{\mathrm{b}}$ & $25.64 \pm 1.46^{\mathrm{a}}$ & $19.73 \pm 1.12^{\mathrm{a}}$ & $1.40 \pm 0.33$ & $1.98 \pm 0.45$ \\
\hline 24 & $76.22 \pm 2.24^{\mathrm{b}}$ & $23.78 \pm 2.24^{\mathrm{a}}$ & $18.30 \pm 1.72^{\mathrm{a}}$ & $1.90 \pm 0.37$ & $1.23 \pm 1.18$ \\
\hline Sex & ns & ns & ns & $* *$ & ns \\
\hline Male & $82.44 \pm 2.38$ & $17.56 \pm 2.38$ & $13.51 \pm 1.83$ & $1.63 \pm 0.24^{\mathrm{b}}$ & $1.84 \pm 0.87$ \\
\hline Female & $82.12 \pm 2.51$ & $17.88 \pm 2.51$ & $13.76 \pm 1.93$ & $2.18 \pm 1.28^{\mathrm{a}}$ & $1.88 \pm 0.59$ \\
\hline Weight & ns & ns & ns & $* *$ & ns \\
\hline Light & $81.96 \pm 2.86$ & $18.04 \pm 2.86$ & $13.88 \pm 2.20$ & $1.53 \pm 0.45^{b}$ & $1.66 \pm 1.07$ \\
\hline Medium & $81.81 \pm 3.23$ & $18.19 \pm 3.23$ & $13.99 \pm 2.49$ & $1.40 \pm 0.83^{b}$ & $1.99 \pm 0.55$ \\
\hline Heavy & $83.04 \pm 3.19$ & $16.96 \pm 3.19$ & $13.05 \pm 2.45$ & $2.80 \pm 1.91^{\mathrm{a}}$ & $1.14 \pm 0.67$ \\
\hline
\end{tabular}

\section{REFERENCES}

1. Mielnic, M.B., K. Aaby, K. Rolfsen,M.R. Ellekjaer, A. Nilsson. Quality of comminuted sausages formulated from mechanically deboned poultry meat. Meat Science 61: 73-84, 2002.

2. Robbins, G. E. S. Quail, their breeding and management. World Pheasant Association (WPA). Pp. 1-10, 1981.

3. Garwood, V.A., R.C.J. Diehl. Body volume and Density of live coturnix quail and associated genetic relationships. Poultry Science Journal 66(8):1269-1272, 1987.

4. Narayan, R., D. P. Singh. Japanese quail breeding: present status and future strategies. In: P.V.K. Sasidhar (Ed.). Poultry Research Priorities to 2020. Proceedings of National Seminar (November 2-3). Central Avian Research Institute, Izatnagar-243 122 (India), 2006.

5. Grey, T.C., D. Robinson, J.M. Jones, S.W. Stock, N.L. Thomas. The Effects of Age and Sex on the Composition of Muscles and Skin 
RAJI A. O., et al.

from a Commercial Broiler Strain. British Poultry Science 24:219-231, 1983.

6. Berri, C. Breeding and quality of poultry. In, Mead GC (Ed): Poultry Meat Processing and Quality CRC Press, Cambridge. 21-33, 2004.

7. Almeida, M. I., E. G. Oliveira, P.R. Ramos, P. R., Veiga, K. Dias. Growth performance of meat male quails of two lines under two nutritional environments. Archives of Veterinary Science 7(2):103 - 108, 2002.

8. El-Full, E. A. Effect of slaughter age and sex on carcass composition of Japanese quail. Egyptian Poultry Science Journal 20: 649-661, 2000.

9. Lepore, P. D., H. L. Marks. Growth rate inheritance in Japanese quail 4. Body composition following four generations of selection under different nutritional environments. Poultry Science 50:1191-1193, 1971.

10.AOAC. Association of Official Analytical Chemists. Official Methods of Analysis, 15th Ed. Washington, D.C, 1990.

11.SPSS, Statistical Programme for Social Sciences, SPSS inc. USA, 2007

12.Kul, S., I. Seker, O. Yildirim. Effect of separate and mixed rearing according to sex on fattening performance and carcass characteristics in Japanese quails (Coturnix coturnix japonica) Archiv Tierzucht Dummerstorf 49(6):607-614, 2006.

13.Abdel-Azeem, F.A. The influence of different stocking density and sex on productive performance and some physiological traits of Japanese quail. Egyptian Poultry Science Journal 30 (I):203-227, 2010.

14.Banerjee, S. 2010. Carcass studies of Japanese quails reared in hot and humid climate of eastern India. World Applied Sciences Journal 8(2):174-176, 2010.

15.Kocak, C. Quail production. Aegean Zootechny Association publications. No: 1, Bilgehan Pres., Izmir, Turkey, 1985.

16.Tserveni-Gousi A. S., A. L. Yannakopoulos. Carcass characteristics of Japanese quail at 42 days of age. British Poultry Science 27:123127, 1986.

17.Caron, N., F. Minvielle, M. Desmarais, L.M. Poste. Mass selection for 45 day body weigh in Japanese quail: Selection response, carcass composition, cooking properties and sensory characteristics. Poultry Science 69:1037-1045, 1990.

18.Bacon, W. L., K. E. Nestor. Divergent selection for body weight and yolk precursor in Coturnix coturnix japonica. 4-Correlated responses in carcass composition and carcass yield of progeny during growth. Poultry Science 62:537-544, 1983.

19.Ozbey, O., M. Ozcelik. The effect of high environmental temperature on growth performance of Japanese quails with different body weights. International Journal of Poultry Science 3: 468-470, 2004.

20.(20)Yalcin, S., I. Oguz, S. Otles. Carcass characteristics of quail (Coturnix japonica) slaughtered at different ages. British Poultry Science 36: 393-399, 1995.

21.Choudhary,M.K. and Mahadevan, I.D. Studies on the effect of age and sex on slaughter characteristics of quails (Coturnix coturnix japonica). Indian Journal of Animal Science 18:33-36, 1983.

22.El-Full, E. A., A.A. Ali, M. H. Abdel-Fattah, M. A. Khalifa. Genetic parameters of some carcass characteristics and chemical composition in Japanese quail. Egyptian Poultry Science Journal. 21:741-763, 2001.

23.Abdel Mounsef, N. A. Non genetic factors affecting some productive traits in Japanese quail. Faculty of Agriculture, Al-Azhar University, Cairo, Egypt M.Sc. Thesis, 2005.

24.(24)Rondelli, S., O. Martinez, O., P. Garcia. Sex effect on productive parameters, carcass and body fat composition of two commercial broilers lines. Brazilian Journal of Poultry Science 3:169-173, 2003.

25.Abdel-hakim, N.F., A.A. Abdel-hady, F. A., Abdel-azeem, G. A. Abdel-hafez. Growth performance and nature of growth of Japanese quail as affected with dietary energy sources, levels and age under the Egyptian environmental condition. Egyptian Poultry Science Journal 29(3):777-804, 2009.

26.Kubena, L. F., B. D. Lott, J. W. Deaton, F. N. Reece, J. D. May. Body composition of chickens as influenced by environmental temperature and selected dietary factors. Poultry Science 51: 517-522, 1972.

27.Boni, I., Nurul, H. and Noryati, I. Comparison of meat quality characteristics between young and spent quails. International Food Research Journal 17: 661-666. 2010

28.Genchev, A., Mihaylova, G., Ribarski, S., Pavlov, A. and Kabakchiev, M. Meat quality and composition in Japanese quails. Trakia Journal of Science 6(4): 72-82, 2008.

29. Yannakopoulos, A.L., E. Cristaki, P. Florou. Effect of age and carcass composition on the onset of sexual maturity in quail under normal feeding regimes. British Poultry Science 36:771-777, 1995. 
RAJI A. O., et al. 